\title{
Applicability of WaveWatch-III wave model to fatigue assessment of offshore floating structures
}

\author{
Tao Zou ${ }^{1}$ (D) Miroslaw Lech Kaminski ${ }^{1}$
}

Received: 1 March 2016 / Accepted: 28 July 2016/Published online: 15 August 2016

(C) The Author(s) 2016. This article is published with open access at Springerlink.com

\begin{abstract}
In design and operation of floating offshore structures, one has to avoid fatigue failures caused by action of ocean waves. The aim of this paper is to investigate the applicability of WaveWatch-III wave model to fatigue assessment of offshore floating structures. The applicability was investigated for Bluewaters' FPSO (Floating Production, Storage and Offloading) which had been turret moored at Sable field for half a decade. The waves were predicted as sea-state time series consisting of one wind sea and one swell. The predicted waves were compared with wave data obtained from ERAinterim and buoy measurements. Furthermore, the fatigue calculations were also carried out for main deck and side shell locations. It has been concluded that predicted fatigue damages of main deck using WaveWatch-III are in a very good agreement regardless of differences in predicted wind waves and swells caused by differences in wave system partitioning. When compared to buoy measurements, the model underestimates fatigue damages of side shell by approximately $30 \%$. The reason for that has been found in wider directional spreading of actual waves. The WaveWatch-III wave model has been found suitable for the fatigue assessment. However, more attention should be paid on relative wave directionality, wave system partitioning and uncertainty analysis in further development.
\end{abstract}

Responsible Editor: Oyvind Breivik

This article is part of the Topical Collection on the 14th International Workshop on Wave Hindcasting and Forecasting in Key West, Florida, USA, November 8-13, 2015

Tao Zou

T.Zou@tudelft.nl

1 Department of Maritime and Transport Technology, Delft University of Technology, 2628 CD Delft, The Netherlands
Keywords Wave models · Fatigue assessment · Offshore floating structures $\cdot$ FPSO

\section{Introduction}

In general, a floating offshore system consists of a floater, risers, subsea installation and either mooring lines or a dynamic positioning system which is an attractive alternative for deep water applications. Most of the floating systems are continuously subjected to action of waves, current and wind. In structural members and joints of floaters, the waves produce varying stresses, which initiate and drive fatigue cracks. Subsequently, these cracks may grow through the thickness, causing a leakage. Further crack propagation may even lead to a structural disjointing failure. In both the design and operation stages of floaters, one has to demonstrate that fatigue failures cannot occur during the design lifetime of e.g. 25 years multiplied by the fatigue safety factor varying between 1 and 10 depending on criticality and reliability of considered structural members or joints. The fatigue failure depends on many factors such as stress variability and production quality (DNV GL 2014). In this investigation, only stress variability caused by waves is considered. Because, on the one hand, it is the main factor causing fatigue failure, and on the other hand, waves are probably affected by the climate change which will be considered in the later research.

It is evident that future waves are not known, and that in order to assess fatigue lifetime, one has to predict them. The prediction is based on the assumption that wave data measured in the past are representative for the future waves. In the operational stage of floaters, the fatigue lifetime estimation can be continuously updated based on wave monitoring, as it is done in the Monitas system (Kaminski and Aalberts 2010). However, in the design stage, wave data in some particular sea 
areas could be limited due to the lack of measurement. One possible solution is the reanalysis of wave data by wind-driven wave models. These reanalysis wave data could be regarded as the representation of past wave climate.

Nowadays, numerical wave models are of the third generation. These models are driven by wind forces, and can numerically simulate wind-wave interactions, nonlinear wavewave interactions, and energy dissipation (Janssen 2008). The most widely used wind-driven wave models are Ocean Wave Model (WAM) (Komen et al. 1994), Simulating WAves Nearshore model (SWAN), and WaveWatch-III model (Tolman 2014). All three models originated from research at Delft University of Technology. So far, the wave simulation ability of WaveWatch-III has already been validated by many studies, but no one has ever considered the applications of this model to fatigue assessment of floaters (Tolman 2002; Mentaschi et al. 2015). In this paper, the suitability of WaveWatch-III wave model for fatigue assessment of floaters is investigated by comparing predicted and measured waves and fatigue damages.

In the first two sections, wave data formats and wave models are discussed. Then, a case study is introduced. After that, results are presented, and finally, conclusions are made.

\section{Wave data formats}

The offshore floating systems are usually designed using sitespecific environmental data, which are prepared by metocean engineers based on available measurements. In general, the amount of environmental data for the design lifetime (say 20 years) is enormous. Therefore, these data are reduced and presented in a compact way as a combination of stationary sea-states that last for constant periods of several hours. In the present study, a period of $6 \mathrm{~h}$ was selected. Each seastate consists of one, two or several wave systems. There are two types of wave systems: wind waves (wind seas) and swells. Wind waves are driven by local wind at given site. Swells are generated by remote wind and propagated to the considered site from remote sea areas. A wave system is usually represented by the significant wave height $\mathrm{H}_{\mathrm{s}}$, the mean zero up-crossing period $\mathrm{T}_{\mathrm{z}}$, the mean direction $\theta$ and the directional spreading coefficients which are quantified from wave spectra. JONSWAP and Pierson-Moskowitz (PM) spectra are typical spectral density functions used in the design of floating offshore structures. A fatigue analysis, a sea-keeping analysis or any other analysis comprising a sea-state is called the short-term analysis. Sea-states to be expected during the design lifetime are typically defined by either the scatter diagram or the sea-state time series. The scatter diagram is the joint probability distribution function of $\mathrm{H}_{\mathrm{s}}$ and $\mathrm{T}_{\mathrm{z}}$. This diagram can be further refined per direction (as a rule per eight geographical directions: N, NE, E, SE, S, SW, W and NW), per season (typically per four seasons) and/or per wave system (typically per wind wave or per swell). However, in all these scatter diagrams joint information between wind waves and swells is lost. This may result in non-conservative fatigue lifetime estimations, especially when associated stress components are multiaxial and non-proportional (van Lieshout et al. 2016). This problem can be avoided by using the sea-state time series. In general, the time series consists of 30 thousands successive sea-states which consist of one wind wave system and one or two swell systems per sea-state. In the present study, one swell is used following the same assumption made in the Monitas system (Kaminski and Aalberts 2010). An analysis comprising a whole design lifetime is called the long-term analysis. An example of sea-state time series is given in Table 1.

Once the sea-states are known, the following fatigue assessment for floating offshore structures is based on spectral analysis which is shortly described in section 4 .

The directionality of wave systems influences the way a floater is moored at a site, as shown in Fig. 1. When wave systems are coming from predominantly one direction, then the best solution is to apply the spread mooring system. In this way, the mean geographical direction of the floater is fixed and equals the predominant direction of wave systems. The floater can still change its direction by a few degrees depending on the rotational stiffness of the mooring system. In other cases, i.e. when wave systems are coming from varying directions, the turret mooring system is a better choice. This is because the floater can be positioned in the direction resulting in minimal roll motions, which are essential for proper functioning of separation process equipment placed on floater's main deck. The instantaneous direction of minimal roll motions depends on actual sea state characteristics, e.g. as those given in Table 1, and constant hydrodynamic characteristics of the floater.

\section{Wave model}

All the 6-hourly wave conditions, either wind waves or swells, are simulated in this research by the wind-driven WaveWatchIII wave model developed at NOAA/NCEP in the spirit of the WAM model (Tolman 2014). It is a further development of the model WaveWatch, as developed at Delft University of Technology and WaveWatch-II, developed at NASA, Goddard Space Flight Center (e.g., Tolman 1992). WaveWatch-III is capable of explicitly simulating the physical process of wave growth, wave propagation and wave dissipation in two dimensions based on wind and bathymetry data.

The wind data required for running WaveWatch-III were obtained from ERA-Interim project (ERA stands for ECMWF Re-Analysis, ECMWF is the European Centre for MediumRange Weather Forecasts). ERA-Interim is a global 
Table 1 An example of sea-state time series

\begin{tabular}{|c|c|c|c|c|c|c|c|c|}
\hline \multirow{3}{*}{$\begin{array}{l}\text { Sea state } \\
\text { number }\end{array}$} & \multicolumn{4}{|l|}{ Wind wave } & \multicolumn{4}{|l|}{ Swell } \\
\hline & $\begin{array}{l}\text { Significant } \\
\text { wave height }\end{array}$ & $\begin{array}{l}\text { Mean zero up- } \\
\text { crossing period }\end{array}$ & $\begin{array}{l}\text { Mean } \\
\text { direction }\end{array}$ & $\begin{array}{l}\text { Directional } \\
\text { spreading } \\
\text { coefficient }\end{array}$ & $\begin{array}{l}\text { Significant } \\
\text { wave height }\end{array}$ & $\begin{array}{l}\text { Mean zero up- } \\
\text { crossing period }\end{array}$ & $\begin{array}{l}\text { Mean } \\
\text { direction }\end{array}$ & $\begin{array}{l}\text { Directional } \\
\text { spreading } \\
\text { coefficient }\end{array}$ \\
\hline & $\begin{array}{l}\mathrm{H}_{\mathrm{s}} \\
{[\mathrm{m}]}\end{array}$ & $\begin{array}{l}\mathrm{T}_{\mathrm{z}} \\
{[\mathrm{s}]}\end{array}$ & $\begin{array}{l}\theta \\
{[\mathrm{deg}]}\end{array}$ & $\begin{array}{l}\mathrm{s} \\
-\end{array}$ & $\begin{array}{l}\mathrm{H}_{\mathrm{s}} \\
{[\mathrm{m}]}\end{array}$ & $\begin{array}{l}\mathrm{T}_{\mathrm{z}} \\
{[\mathrm{s}]}\end{array}$ & $\begin{array}{l}\theta \\
{[\operatorname{deg}]}\end{array}$ & $\begin{array}{l}\mathrm{s} \\
-\end{array}$ \\
\hline 1 & 1.0 & 7.0 & 230 & 8 & 3.0 & 14.0 & 140 & 15 \\
\hline 2 & 2.5 & 8.0 & 250 & 9 & 2.5 & 12.5 & 145 & 20 \\
\hline 3 & 3.5 & 9.0 & 300 & 11 & 2.5 & 12.0 & 150 & 15 \\
\hline$\ldots$ & $\ldots$ & $\ldots$ & $\ldots$ & $\ldots$ & $\ldots$ & $\ldots$ & $\ldots$ & $\ldots$ \\
\hline 30,000 & 5.0 & 9.5 & 95 & 13 & no & no & no & no \\
\hline
\end{tabular}

atmospheric reanalysis project covering the period from 1979 to the present. It is using WAM to simulate the global waves with $1.0^{\circ} \times 1.0^{\circ}$ latitude/longitude grid and 6-hourly interval (Janssen et al. 2005; Dee et al. 2011).

The bathymetry data required for running WaveWatch-III were obtained from the ETOPO1 model developed by the National Oceanic and Atmospheric Administration. ETOPO1 provides complete global topographic and bathymetric coverage including ice coverage with one arc-minute resolution. The data in this model were obtained from US government agencies, international agencies, and academic institutions (Amante and Eakins 2009).

The wave data obtained from WaveWatch-III will be directly compared with the wave data obtained from ERAInterim project and buoy measurements.

\section{Case study}

The applicability of WaveWatch-III model was investigated for the case of the FPSO Glas Dowr which was turret moored at Sable Field, offshore South Africa $\left(35.21^{\circ} \mathrm{S}, 21.32^{\circ} \mathrm{E}\right)$ for 5 years starting from 2003 . Wave data are simulated and fatigue damages are calculated for 10 years starting from year 2000. The FPSO is a converted FPSO owned by Bluewater. The main characteristics of the Glas Dowr FPSO are listed in Table 2 .
As introduced above, wave conditions were simulated by WaveWatch-III using bathymetry data obtained from the ETOPO1 model and wind data obtained from ERA-interim project. The spatial resolution of ERA-interim wind data in this validation case is $0.75^{\circ} \times 0.75^{\circ}$ latitude/longitude. The selected numerical settings include the third propagation scheme, discrete interaction approximation, and Ardhuin et al.'s source term package (2010) for input and dissipation. A global simulation was carried out because Sable Field is exposed to swells coming from both the Atlantic and Indian Ocean as shown in Fig. 2. The output was 6-hourly wave spectra defined for 24 equally spaced directions (i.e. every $15^{\circ}$ ) and 25 frequencies in the range starting from $0.042 \mathrm{~Hz}$ up to $0.414 \mathrm{~Hz}$ and frequency increment multiplier of 1.1. In each sea-state, wind waves and several swells were partitioned based on Hanson and Phillips' method (2001). In order to simplify the fatigue damage calculation, all swells were combined into one swell based on the wave energy conservation. Finally, wave directional spreading for wind waves and swells was removed by attributing the integral of spectral density over wave direction to the mean wave direction. In this way, each wave system was represented by $\mathrm{H}_{\mathrm{s}}, \mathrm{T}_{\mathrm{z}}$ and mean wave direction. This is consistent with methods implemented in the Monitas system for the FPSO Glas Dowr.

Wave direction with respect to the floater direction, i.e. the relative wave direction, is an important element for assessing fatigue lifetime. As explained above, the relative wave direction is dependent on the mooring system. The FPSO Glas
Fig. 1 Spread moored floater (a) and turret moored floater (b) (www.bluewater.com)
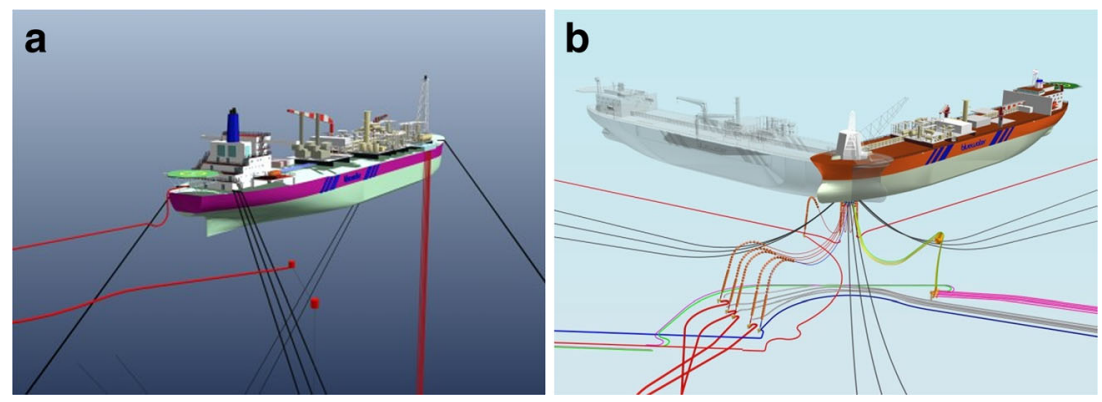
Table 2 Main characteristics of the Glas Dowr FPSO

\begin{tabular}{lclc}
\hline Displacement & $\begin{array}{c}121,400 \\
\text { metric tons }\end{array}$ & Depth & $21.2 \mathrm{~m}$ \\
$\begin{array}{l}\text { Length between } \\
\text { perpendiculars (Lpp) }\end{array}$ & $232 \mathrm{~m}$ & $\begin{array}{c}\text { Assumed } \\
\text { midship draft }\end{array}$ & $12.99 \mathrm{~m}$ \\
$\begin{array}{l}\text { Breadth } \\
\text { Water depth }\end{array}$ & $103 \mathrm{~m}$ \\
\hline
\end{tabular}

Dowr is turret moored. However, for the sake of validation of WaveWatch-III wave model, three methods for calculating the relative wave directions associated with the mooring types were considered:

1. Spread mooring system. In this case, the relative wave directions equal the geographical wave directions corrected for the floater direction which is assumed to face South in this paper.

2. Turret mooring system. First the floater direction was calculated in a simplified way as the geometrical sum of wind waves and swell vectors. These vectors had magnitudes of significant wave heights and directions of waves. After that, the relative wave directions were calculated by correcting the geographical wave directions for the floater direction. In the later research, the authors will use the relative wave directions calculated by Bluewater using dedicated software.
3. Fictive mooring system. In this case, all waves were assumed to be head waves $\left(180^{\circ}\right.$ off stern) independent of actual wave and floater directions. This kind of mooring system does not exist, but it was introduced in order to validate WaveWatch-III model depending on wave heights and periods and eliminating the influence of wave directions.

After determination of wind waves and swells together with their relative directions for each 6-hourly sea-state, the next step was calculating annual fatigue damage for two locations described in Table 3. The fatigue damage was calculated using the Monitas system that is installed on board the FPSO Glas Dowr. In this system, the fatigue calculation program Bluefat is incorporated. Bluefat was developed by Bluewater in the spirit of the program Nefada which was developed by the second author based on earlier versions of DNV GL (2014). In the Monitas system, a wave partitioning scheme is also used to identify wind waves and swells by an inverse watershed algorithm to isolate peak domains in directional wave spectra (Hanson and Phillips 2001). More details about Monitas system can be found in Aalberts et al. (2010). In general, the Bluefat program uses a conventional spectral fatigue assessment method with a correction for the intermittent wetting effect. The program comprises hydrodynamic



Fig. 2 The location of Sable Field. Sable Field is exposed to swells coming from both the Atlantic and Indian Ocean 
Table 3 Selected locations for fatigue lifetime calculations

\begin{tabular}{llllll}
\hline $\begin{array}{l}\text { Location } \\
\text { identifier }\end{array}$ & \multicolumn{2}{c}{ Position $^{\mathrm{a}}[\mathrm{m}]$} & \multicolumn{2}{c}{ Description } \\
\cline { 3 - 5 } 1 & $\mathrm{x}$ & $\mathrm{y}$ & $\mathrm{z}$ & \\
\hline NA & 112.85 & 18.3 & 21.31 & $\begin{array}{l}\text { On the main deck at frame } 661 / 2 \text { above deck longitudinal \#22. } \\
\text { This is location } 1 \text { in Kaminski (2007). } \\
\text { On web of the side shell longitudinal \#34, 50 mm from ship's side, } \\
\text { this stiffener is at the vertical position almost equal to the } \\
\text { position of the neutral axis for the vertical bending of the } \\
\text { midship cross section of the floater. } \\
\text { This is location } 4 \text { in Kaminski (2007). }\end{array}$ \\
\hline
\end{tabular}

${ }^{\text {a }}$ The coordinate system is shown in Fig. 1 analysis, stress analysis and fatigue analysis. Note that the stress analysis is based on simple beam models rather than the finite element method. Four loading mechanisms are taken into account: overall vertical and horizontal bending of the floater, and local bending of secondary stiffeners caused by external action of waves and internal tank pressure fluctuations induced by varying motions of the floater. The Response Amplitude Operators (RAOs) of these load components were provided by Bluewater. Example of RAOs for Midship Vertical Bending Moment is shown in Fig. 3. The fatigue resistance was assumed to be represented by a oneslope S-N curve with $m=3$ and $\log (\mathrm{C})=5.75$ with stresses in $\mathrm{MPa}$.

In order to validate WaveWatch-III wave model, the fatigue calculations were also carried out with the wave data obtained from ERA-interim and from buoy measurement. The wave data of ERA-interim is simulated with WAM wave model. The buoy measured data are considered the most reliable. The buoy records are produced every $30 \mathrm{~min}$, and the 6hourly averaged $\mathrm{H}_{\mathrm{s}}, \mathrm{T}_{\mathrm{z}}$ and wave direction of buoy data are used in this case study. However, the buoy-measured wave data at Sable Field collected by Maritime Research Institute Netherlands (MARIN) are only available from November 2007 to October 2008 (Aalberts et al. 2010). Hence, the comparison between WaveWatch-III and ERA-interim have been done using the annual fatigue damages, starting from 2000 and ending in 2009, whereas, the comparison between WaveWatch-III, ERA-interim and the buoy measurement have been done using the monthly fatigue damages. Please notice there are three wave datasets in this study: wave data simulated with WaveWatch-III, wave data obtained from ERA-interim project and wave data measured by buoy. Wave data from ERA-interim are simulated and partitioned by WAM wave model.

\section{Results}

First, the wave data predicted by WaveWatch-III are compared with the wave data obtained from ERA-interim and the buoy measurements. The spatial resolution of ERA-interim wave data is also $0.75^{\circ} \times 0.75^{\circ}$ latitude/longitude grid. It should be noted that wave systems with $\mathrm{H}_{\mathrm{s}}<1 \mathrm{~m}$ were disregarded, because they hardly contribute to the fatigue damage of floaters. Further, it was decided to reduce the data to a presentable size, because the time interval spans over 10 years and in each year there are on average 1461 6-hourly sea states. Therefore, Table 4 shows annual average wave parameters of sea-states $\mathrm{H}_{\mathrm{s}}, \mathrm{T}_{\mathrm{z}}$ and $\theta$ for WaveWatch-III predictions, ERA-interim, and buoy measurement. In addition, the numbers of predicted wind waves and swells are shown. The last column shows percentage of combined seas, i.e. how often both wave systems were simultaneously occurring. The last rows show the mean values and coefficients of variance of annual averages.

Several conclusions have been drawn based on results presented in Table 4:

1. As shown in the last row, the coefficients of variation of annual averages are low (ranging from 0.1 to $11 \%$ with the average of $3 \%$ ), indicating that the wave climate at the Sable Field was not varying much in the considered years.

2. The differences between the average wave data predicted by WaveWatch-III and obtained from ERA-interim are consistent over considered years.

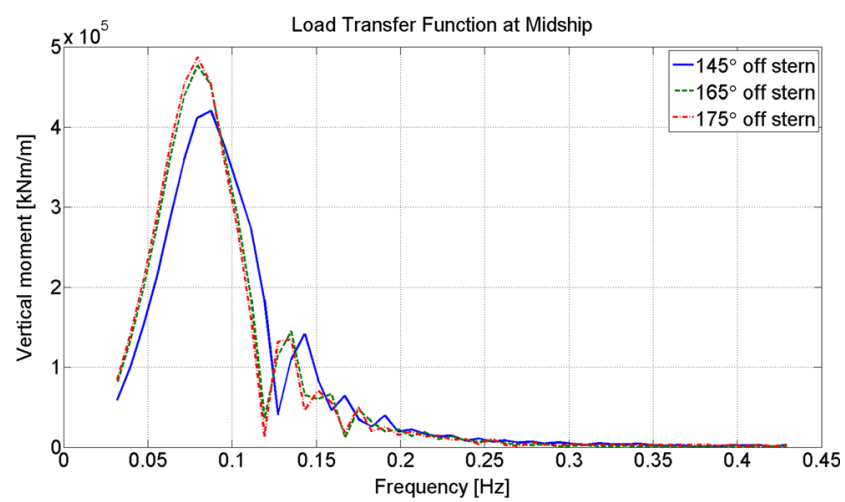

Fig. 3 Examples of response amplitude operators of midship vertical bending moment 
Table 4 Annual average wave parameters of sea-states for WaveWatch-III, ERA-interim, and buoy measurement

\begin{tabular}{|c|c|c|c|c|c|c|c|c|c|c|}
\hline \multirow[t]{3}{*}{ Year } & \multirow[t]{3}{*}{ Data set } & \multicolumn{4}{|c|}{ Wind waves } & \multicolumn{4}{|l|}{ Swell } & \multirow{3}{*}{$\begin{array}{l}\mathrm{N}_{\mathrm{w} / \mathrm{s}}{ }^{\mathrm{b}} \\
{[\%]}\end{array}$} \\
\hline & & \multicolumn{3}{|c|}{ Annual average values } & \multirow{2}{*}{$\begin{array}{l}\mathrm{N}_{\mathrm{w}} \\
-\end{array}$} & \multicolumn{3}{|c|}{ Annual average values } & \multirow{2}{*}{$\begin{array}{c}\mathrm{N}_{\mathrm{s}} \\
-\end{array}$} & \\
\hline & & $\begin{array}{l}\mathrm{H}_{\mathrm{s}} \\
{[\mathrm{m}]}\end{array}$ & $\begin{array}{l}\mathrm{T}_{\mathrm{z}} \\
{[\mathrm{s}]}\end{array}$ & $\begin{array}{l}\theta \\
{[\mathrm{deg}]}\end{array}$ & & $\begin{array}{l}\mathrm{H}_{\mathrm{s}} \\
{[\mathrm{m}]}\end{array}$ & $\begin{array}{l}\mathrm{T}_{\mathrm{z}} \\
{[\mathrm{s}]}\end{array}$ & $\begin{array}{l}\theta \\
{[\operatorname{deg}]}\end{array}$ & & \\
\hline \multirow[t]{3}{*}{2000} & WaveWatch-III & 2.42 & 6.76 & 184 & 765 & 1.91 & 8.06 & 187 & 1028 & 23 \\
\hline & ERA-interim & 1.82 & 4.62 & 191 & 507 & 2.45 & 8.93 & 204 & 1464 & 35 \\
\hline & Difference & 0.61 & 2.14 & -7 & 258 & -0.54 & -0.88 & -17 & -436 & 12 \\
\hline \multirow[t]{3}{*}{2001} & WaveWatch-III & 2.42 & 6.71 & 182 & 762 & 1.88 & 7.96 & 186 & 1046 & 24 \\
\hline & ERA-interim & 1.93 & 4.74 & 194 & 526 & 2.49 & 9.04 & 204 & 1460 & 36 \\
\hline & Difference & 0.49 & 1.97 & -12 & 236 & -0.60 & -1.08 & -18 & -414 & 12 \\
\hline \multirow[t]{3}{*}{2002} & WaveWatch-III & 2.59 & 6.95 & 190 & 707 & 1.94 & 8.01 & 190 & 1002 & 17 \\
\hline & ERA-interim & 1.95 & 4.76 & 204 & 496 & 2.54 & 9.11 & 208 & 1460 & 34 \\
\hline & Difference & 0.64 & 2.19 & -14 & 211 & -0.61 & -1.10 & -18 & -458 & 17 \\
\hline \multirow[t]{3}{*}{2003} & WaveWatch-III & 2.45 & 6.84 & 199 & 676 & 1.94 & 7.93 & 191 & 1021 & 16 \\
\hline & ERA-interim & 1.77 & 4.58 & 210 & 452 & 2.41 & 8.82 & 210 & 1460 & 31 \\
\hline & Difference & 0.68 & 2.26 & -11 & 224 & -0.48 & -0.90 & -19 & -439 & 16 \\
\hline \multirow[t]{3}{*}{2004} & WaveWatch-III & 2.32 & 6.78 & 192 & 595 & 1.89 & 8.05 & 197 & 1102 & 16 \\
\hline & ERA-interim & 1.76 & 4.55 & 204 & 364 & 2.39 & 8.87 & 212 & 1464 & 25 \\
\hline & Difference & 0.56 & 2.23 & -12 & 231 & -0.50 & -0.83 & -15 & -362 & 9 \\
\hline \multirow[t]{3}{*}{2005} & WaveWatch-III & 2.40 & 6.77 & 194 & 759 & 1.92 & 7.92 & 192 & 1003 & 21 \\
\hline & ERA-interim & 1.84 & 4.63 & 209 & 478 & 2.48 & 8.97 & 207 & 1460 & 33 \\
\hline & Difference & 0.56 & 2.14 & -15 & 281 & -0.56 & -1.05 & -15 & -457 & 12 \\
\hline \multirow[t]{3}{*}{2006} & WaveWatch-III & 2.30 & 6.67 & 189 & 682 & 1.97 & 8.08 & 194 & 1062 & 19 \\
\hline & ERA-interim & 1.77 & 4.57 & 194 & 420 & 2.47 & 8.97 & 207 & 1460 & 29 \\
\hline & Difference & 0.53 & 2.10 & -5 & 262 & -0.51 & -0.88 & -13 & -398 & 10 \\
\hline \multirow[t]{3}{*}{2007} & WaveWatch-III & 2.73 & 7.16 & 196 & 683 & 2.08 & 8.25 & 190 & 1059 & 19 \\
\hline & ERA-interim & 1.99 & 4.82 & 212 & 498 & 2.66 & 9.32 & 207 & 1460 & 34 \\
\hline & Difference & 0.75 & 2.34 & -16 & 185 & -0.58 & -1.07 & -18 & -401 & 15 \\
\hline \multirow[t]{3}{*}{2008} & WaveWatch-III & 2.53 & 6.72 & 191 & 694 & 1.96 & 8.03 & 193 & 1097 & 23 \\
\hline & ERA-interim & 1.96 & 4.75 & 197 & 495 & 2.50 & 9.03 & 206 & 1464 & 34 \\
\hline & Difference & 0.57 & 1.97 & -7 & 199 & -0.54 & -1.00 & -13 & -367 & 11 \\
\hline $11 / 2007-10 / 2008$ & Buoy & 2.77 & 6.00 & $179^{\mathrm{a}}$ & 428 & 2.56 & 8.52 & $198^{\mathrm{a}}$ & 1057 & 26 \\
\hline \multirow[t]{3}{*}{2009} & WaveWatch-III & 2.49 & 6.70 & 185 & 741 & 1.92 & 8.09 & 187 & 1099 & 26 \\
\hline & ERA-interim & 1.93 & 4.74 & 189 & 529 & 2.49 & 8.95 & 204 & 1460 & 36 \\
\hline & Difference & 0.56 & 1.97 & -4 & 212 & -0.57 & -0.86 & -17 & -361 & 10 \\
\hline \multirow[t]{3}{*}{ Mean } & WaveWatch-III & 2.47 & 6.81 & 190 & 706 & 1.94 & 8.04 & 191 & 1052 & 20 \\
\hline & ERA-interim & 1.87 & 4.68 & 200 & 477 & 2.49 & 9.00 & 207 & 1461 & 33 \\
\hline & Difference & 0.59 & 2.13 & -10 & 230 & -0.55 & -0.96 & -16 & -409 & 13 \\
\hline \multirow[t]{2}{*}{ Coefficient of variance [\%] } & WaveWatch-III & 5.2 & 2.2 & 2.8 & 7.5 & 2.9 & 1.2 & 1.8 & 3.7 & 2.8 \\
\hline & ERA-interim & 4.8 & 2.1 & 4.2 & 11 & 3.0 & 1.6 & 1.3 & 0.1 & 2.6 \\
\hline
\end{tabular}

${ }^{a}$ The wave heading measured by buoy is the relative wave heading with respect to the floater

${ }^{\mathrm{b}} \mathrm{N}_{\mathrm{w} / \mathrm{s}}$ represents the fraction where both systems are present

3. WaveWatch-III model predicts higher and longer wind waves than ERA-interim. On average, predicted significant wave heights of wind waves are $0.6 \mathrm{~m}$ higher and predicted mean zero-crossing periods of wind waves are $2 \mathrm{~s}$ longer.
4. The opposite is valid for swells. WaveWatch-III model predicts lower and shorter swells than ERA-interim. On average, predicted significant wave heights of wind waves are $0.6 \mathrm{~m}$ lower and predicted mean zerocrossing periods of swells are $1 \mathrm{~s}$ shorter. 
Wave Directional Distribution from November 2007 to October 2008 (Buoy measurement)
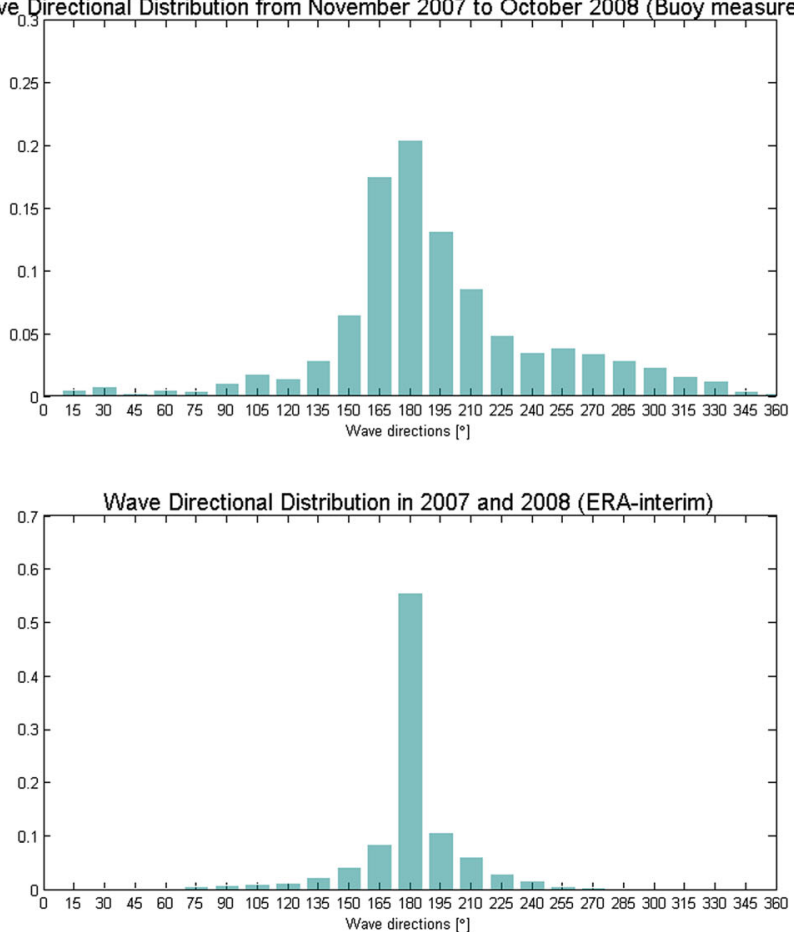

Wave Directional Distribution in 2007 and 2008 (WW3)

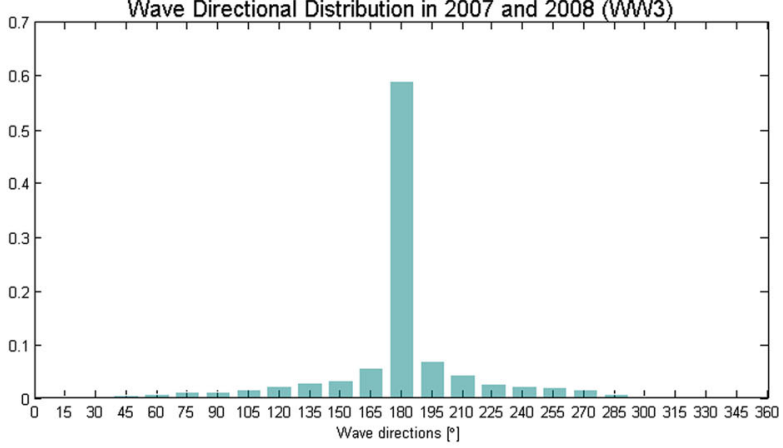

Comparison of Wave Directional Distributions

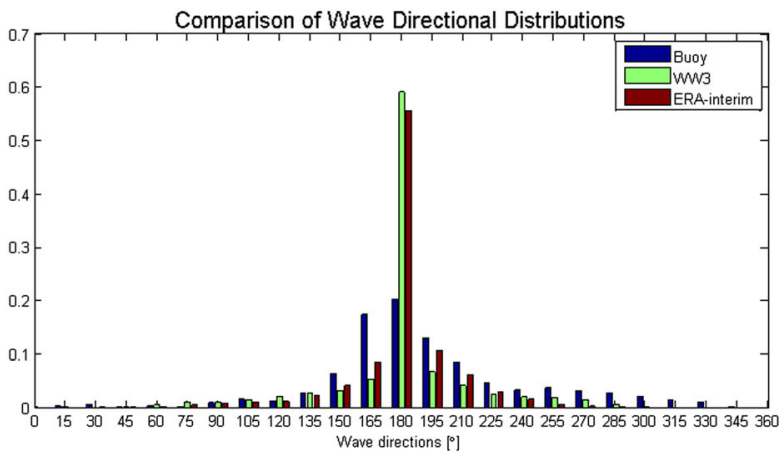

Fig. 4 Relative wave direction distributions of combined sea states in 2007 and 2008

5. WaveWatch-III predicts a significantly different number of wind waves and swells than ERA-interim. The number of wind waves and swells is respectively $50 \%$ higher and $30 \%$ lower.

6. A plausible reason for the conclusions above is the way both models (WaveWatch-III and WAM) partition swells and wind waves. There is no standard way to partition wind waves and swells, and the wave system type determinations are rather empirical. The partitioning scheme of buoy measured data is presented by Hanson and Phillips (2001). A further introduction can be found in Hanson et al. (2010). WaveWatch-III also uses the same scheme. The wave model (WAM) in ERA-interim is using the partitioning scheme presented by Voorrips et al. (1997). Both schemes are adapted from the partitioning approach proposed by Hasselmann et al. (1994). In Hasselmann's approach, wave spectra are divided into subsets to identify each wave system (windsea and swells). Hence, WaveWatch-III and WAM should be expected to give different results in terms of wave partitioning.

7. The total number of wave systems with a significant wave height higher than $1 \mathrm{~m}$ is underestimated by WaveWatch-III by $13 \%$.

8. The wave directions predicted by WaveWatch-III match very well (4\% on average) with those from ERA-interim.

9. Both wave models predict almost the same average directions for wind waves and swells.

10. The number of combined seas predicted by WaveWatchIII model is $40 \%$ lower.
11. The comparison with the buoy measurements can only be made for the year 2008. In this year, the buoy measurements match the prediction of wind waves by WaveWatchIII model and swells from ERA-interim both very well.

Although the average wave directions of combined sea states from WaveWatch-III, ERA-interim and buoy measurements match very well, a close look into distributions of relative wave headings shown in Fig. 4 indicates that the actual spreading of wave directions is larger than those predicted by both wave models, at least in the years 2007 and 2008 .

In the following subsections, the results of annual fatigue damage calculations are presented and discussed in order to investigate WaveWatch-III wave model with respect to its applicability for fatigue calculations. Again, the results are compared with fatigue damages from the same calculations but using the
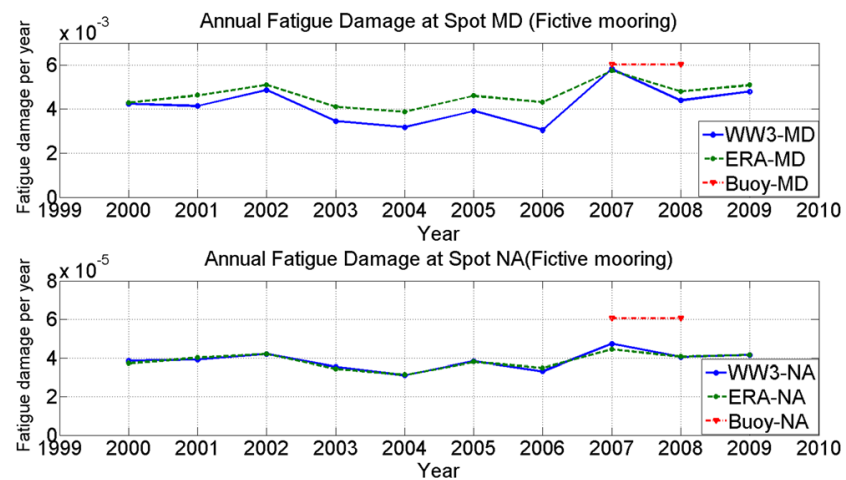

Fig. 5 Annual fatigue damage 2000-2009 (fictive mooring system) 
Fig. 6 Annual fatigue damage 2000-2009 (turret mooring system)
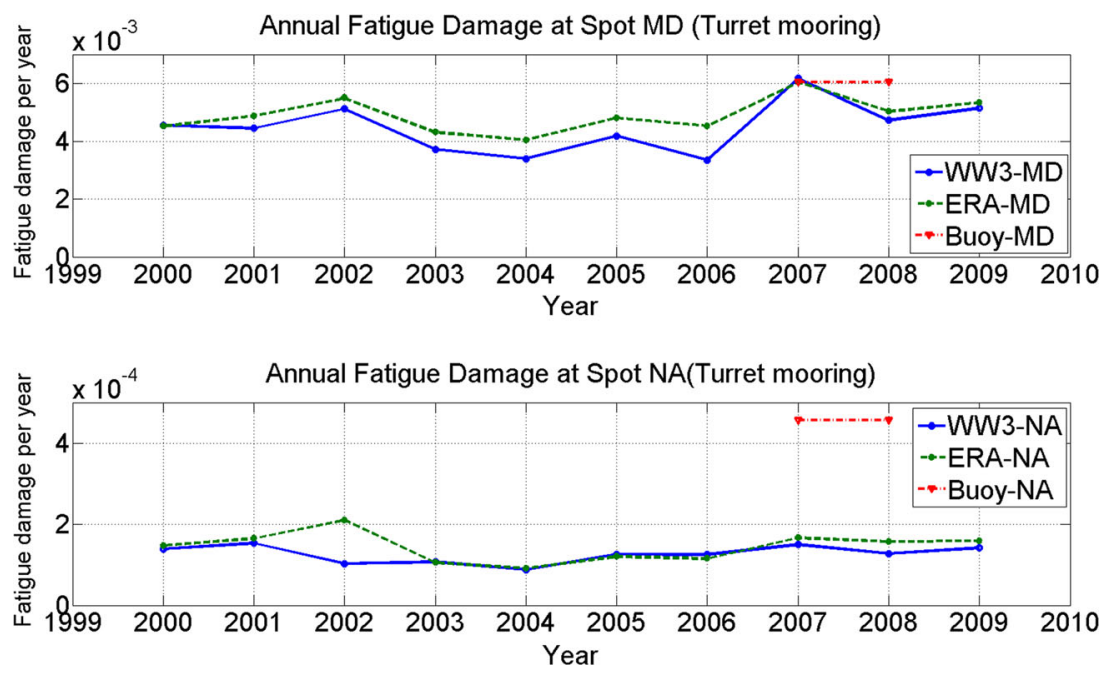

wave data from ERA-interim and buoy measurements. Since there are no entire-year (from January to December) buoy measurements available, the calculated fatigue damage is assumed to correspond to the average value of 2007 and 2008. A better comparison among these three datasets is made in terms of monthly fatigue damages. As explained earlier, the wave directionality is essential for fatigue calculations. Therefore, the calculations were carried out for three cases: turret, spread and fictive mooring systems. These cases differ in the ways the relative wave heading with respect to the floater are calculated.

\subsection{Fictive mooring system}

In this case, the influence of wave directions was eliminated by assuming that all wave systems are head waves. Figure 5 shows the annual fatigue damage at both considered locations. Use of WaveWatch-III wave model underestimates the fatigue damage of the main deck location by approximately $10 \%$ with respect to the damage calculated with ERA-interim wave data and $15 \%$ with respect to the damage calculated with buoy measurements. This comparison result is consistent with the conclusions drawn from Table 4. Apparently, compared to ERA-interim, the fatigue damage caused by swells is underestimated by WaveWatch-III because of the underestimation on swells' $\mathrm{H}_{\mathrm{s}}$ and their occurrence number. In contrast, the higher $\mathrm{H}_{\mathrm{s}}$ and occurrence number of wind seas result in more fatigue consumptions. Consequently, the sum of both fatigue damages calculated with WaveWatch-III wave data is slightly lower that ERA-interim. The annual fatigue damages for both models show the same variation in the considered years. The fatigue damage with WaveWatch-III shows very good agreement with the damage calculated with ERAinterim wave data but is $30 \%$ lower than the damage calculated with buoy measurements. This is consistent with the earlier conclusion that the actual spreading of wave directions is larger than those predicted by both wave models.

\subsection{Turret mooring system}

Figure 6 shows the annual fatigue damage at both considered locations which was calculated using wave data from WaveWatch-III, ERA-interim and buoy measurements. The annual fatigue damages of WaveWatch-III and ERA-interim at
Fig. 7 Annual fatigue damage 2000-2009 (spread mooring system)
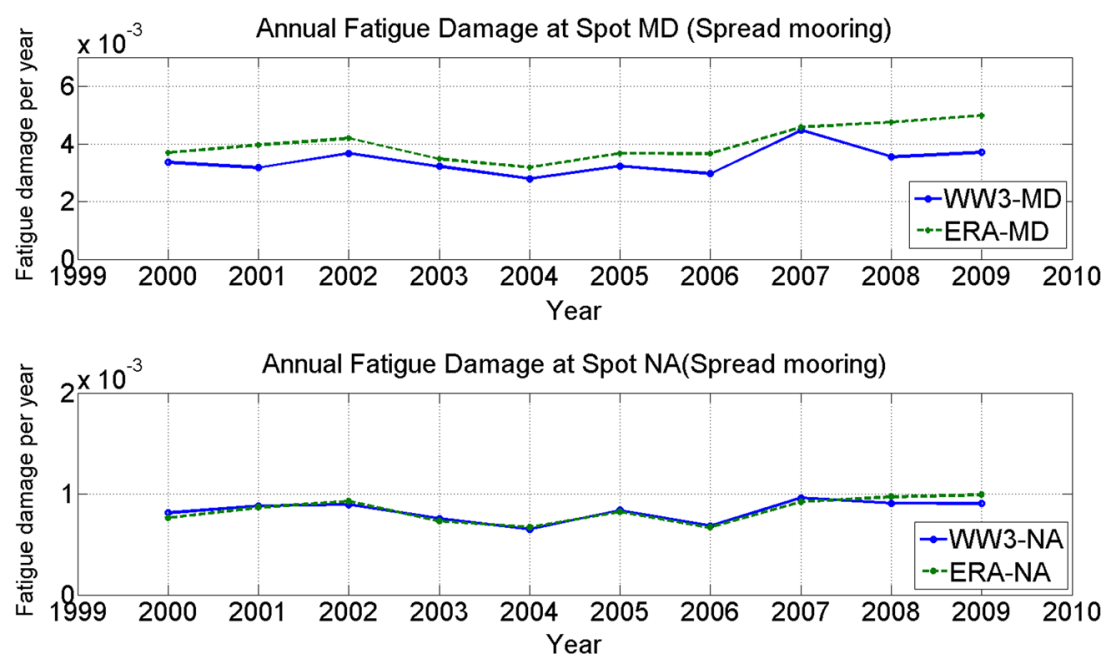
Fig. 8 Monthly fatigue damage from Nov. 2007 to Oct. 2008 (fictive mooring system)
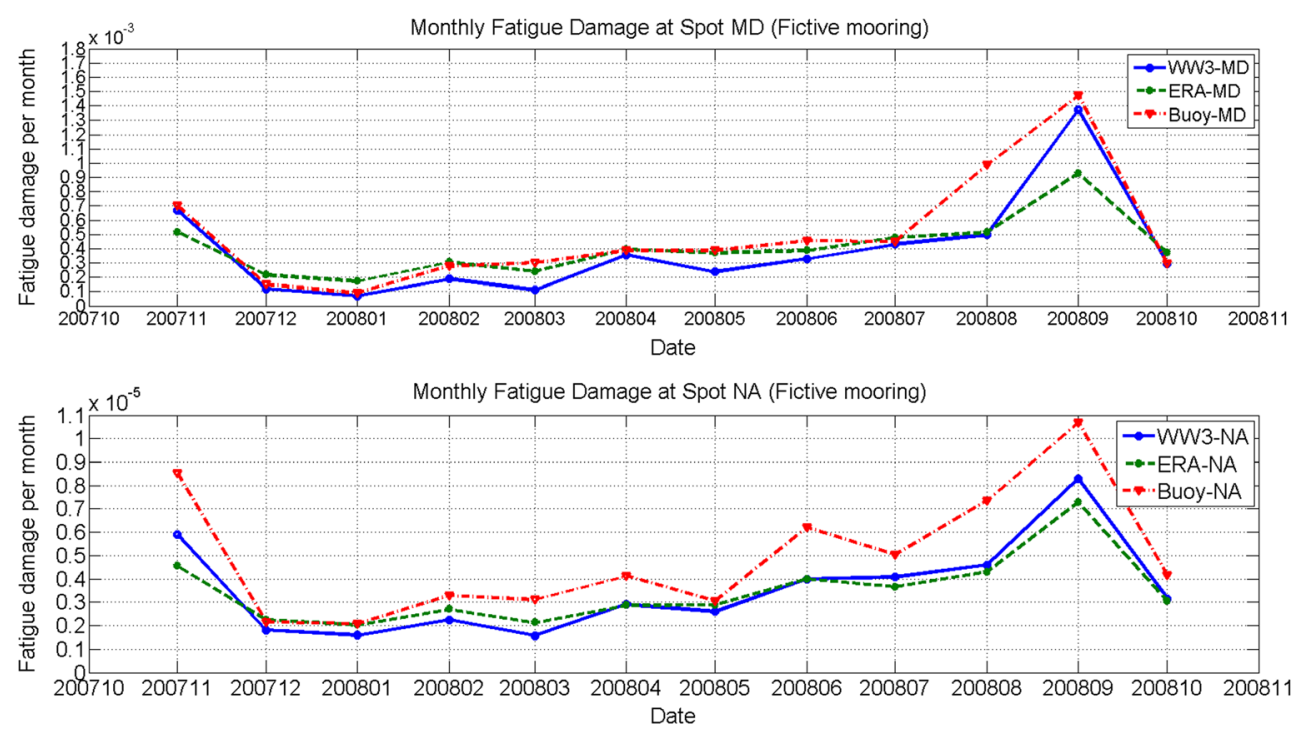

both locations show the same variations in the considered years. The performance of WaveWatch-III wave model for the main deck location is the same as in the previous case. However, both datasets predict higher annual damages by approximately $7 \%$ when compared to the damage calculated with buoy measurements. The annual fatigue damages at the side shell location calculated using both datasets show again a very good agreement (except year 2002). However, the fatigue damages are now two orders higher compared to the fictive mooring system case. The reason for this significant increase is the wider wave directional spreading.

\subsection{Spread mooring system}

Although the Glas Dowr FOSO is turret moored, this case was introduced in order to investigate the influence of relative wave directions on fatigue damage. Compared to the two other cases, this case resulted in more waves coming from both sides of the floater. Consequently, a further significant increase of annual fatigue damage at the side shell location was found as shown in Fig. 7. However, WaveWatch-III wave model still shows a very good agreement with ERA-interim wave model. The annual fatigue damage for the main deck location shows lower values, as was expected. Nevertheless, the agreement between both datasets is similar to what could be observed in two other cases above.

\subsection{Monthly fatigue damage}

A better comparison between WaveWatch-III, ERA-interim and the buoy measurements was based on monthly fatigue damages from November 2007 to October 2008. The results for the first case (Fictive Mooring System) at both locations are shown in Fig. 8. For both locations, the results using WaveWatch-III and
Fig. 9 Monthly fatigue damage from Nov. 2007 to Oct. 2008 (turret mooring system)
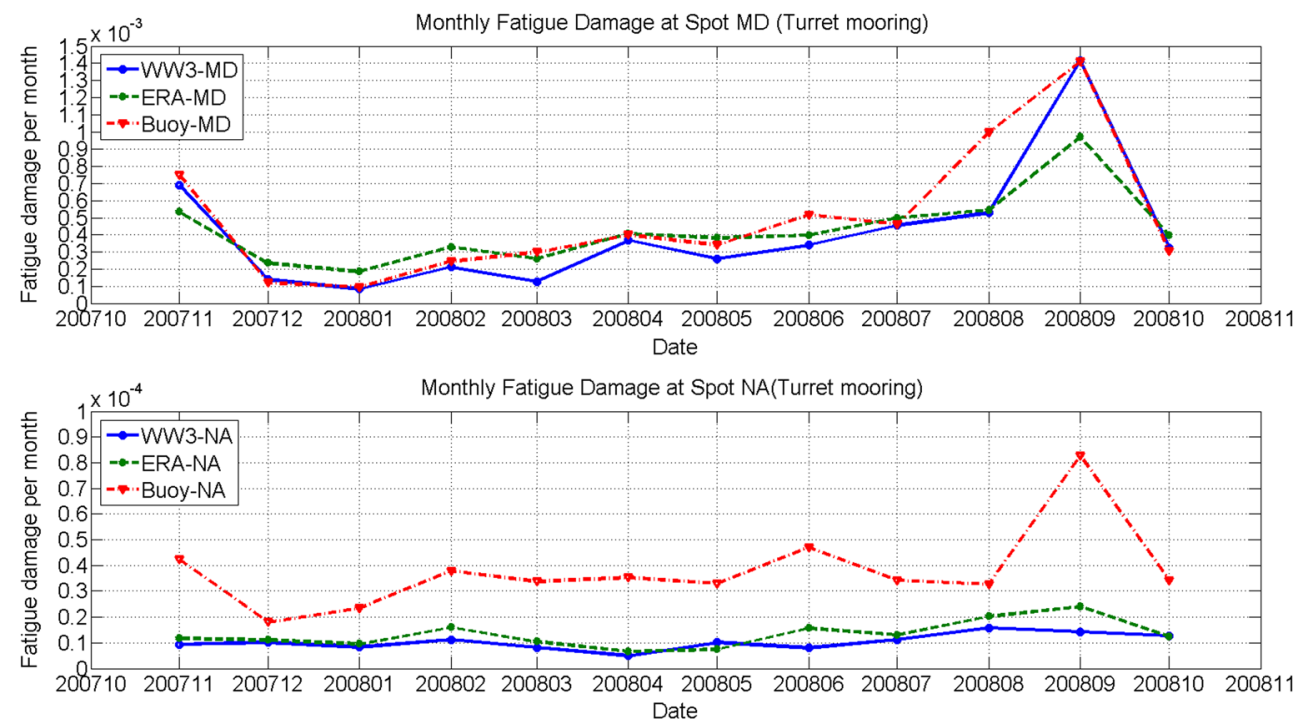
ERA-interim data are very close to each other except in September 2008. The results obtained using buoy measurements show good agreement for the main deck location. For the side shell location, both datasets underestimate monthly fatigue damage by approximately $30 \%$. Figure 9 shows the results at both locations for the second case (turret mooring system). The performance of WaveWatch-III model with respect to ERA-interim is the same as in the case of annual fatigue damage comparisons. The conclusions drawn above remain valid.

\section{Conclusions}

This paper investigated the applicability of WaveWatch-III wave model for simulating waves and evaluated its effects on fatigue damage calculations. Firstly, waves obtained from WaveWatchIII were compared with wave data obtained from ERA-Interim and buoy measurements. After that, annual and monthly fatigue damages at two locations of the Glas Dowr FPSO operating for 10 years were calculated by WaveWatch-III. The results were compared with damages calculated using the other two wave datasets (ERA-interim and buoy measurements).

It has been concluded that although both wave models (WaveWatch-III and WAM) show differences in predicting wind waves and swells, the agreement in predicted annual and monthly fatigue damage is very good. The differences in predicting wind waves and swells have been attributed to the different ways both models classify and partition wind waves and swells. In addition, both models underestimate fatigue damages at side shell by approximately $30 \%$. The reason for that has been found in wider directional spreading of actual waves. In contrast, the fatigue damages calculated with both models at the main deck location are very close to the fatigue damage calculated using wave measurements.

In general, the WaveWatch-III wave model has been found applicable for fatigue assessment. However, more attention should be paid to relative wave directionality and wave system partitioning. There are various uncertainties associated with the presented methodology. The following research will focus on uncertainty analysis.

Acknowledgments This research was partially supported by the China Scholarships Council. Thanks to Pieter Aalberts and Remco Hageman at MARIN for providing buoy-measured data. Thanks to Bluewater for providing structural data of Glas Dowr. ECWMF is also acknowledged for their environmental data.

Open Access This article is distributed under the terms of the Creative Commons Attribution 4.0 International License (http:// creativecommons.org/licenses/by/4.0/), which permits unrestricted use, distribution, and reproduction in any medium, provided you give appropriate credit to the original author(s) and the source, provide a link to the Creative Commons license, and indicate if changes were made.

\section{References}

Aalberts P, van der Cammen J, Kaminski ML (2010) The Monitas system for the Glas Dowr FPSO. Proceedings of Offshore Technology Conference, OTC2010-20873, Houston, Texas, USA

Amante C, Eakins BW (2009) ETOPO1 1 Arc-minute global relief model: procedures, data sources and analysis. NOAA Technical Memorandum NESDIS NGDC-24. National Geophysical Data Center, NOAA. doi: 10.7289/V5C8276M

Ardhuin F, Rogers E, Babanin AV, Filipot JF, Magne R, Roland A, van der Westhuysen A, Queffeulou P, Lefevre JM, Aouf L, Collard F (2010) Semiempirical dissipation source functions for ocean waves. Part I: definition, calibration, and validation. J Phys Oceanogr 40: 1917-1941. doi:10.1175/2010JPO4324.1

Dee DP, Uppala SM, Simmons AJ et al (2011) The ERA-Interim reanalysis: configuration and performance of the data assimilation system. Q J R Meteorol Soc 137:553-597. doi:10.1002/Qj.828

DNV GL (2014) Classification note 30.7: fatigue assessment of ship structures. Det Norske Veritas AS

Hanson J, Phillips OM (2001) Automated analysis of ocean surface directional wave spectra. J Atmos Ocean Technol 18:277-293. doi:10.1175/1520-0426(2001)018<0277:AAOOSD>2.0.CO;2

Hanson J, Lübben A, Aalberts P, Kaminski M (2010) Wave measurements for the Monitas System, Proceedings of Offshore Technology Conference, OTC2010- 20869, Houston, Texas, USA

Hasselmann S, Hasselmann K, Bruning C (1994) Extraction of wave spectra from SAR image spectra. Dynamics and modelling of ocean waves. In: Komen GJ et al (eds) Cambridge University Press, pp 391-401

Janssen PAEM (2008) Progress in ocean wave forecasting. J Comput Phys 227(7):3572-3594. doi:10.1016/j.jcp.2007.04.029

Janssen PAEM, Bidlot JR, Abdalla S, Hersbach H (2005) Progress in ocean wave forecasting at ECMWF. Technical Memoranda, 478, UK

Kaminski ML (2007) Sensing and understanding fatigue lifetime of new and converted FPSOs, Proceedings of Offshore Technology Conference, OTC2007-18913, Houston, Texas, USA

Kaminski ML, Aalberts P (2010) Implementation of the Monitas system for FPSO units, Proceedings of Offshore Technology Conference, OTC2010-20871, Houston, Texas, USA

Komen G J, Cavaleri L, Donelan M, Hasselmann K, Hasselmann S, Janssen PAEM (1994) Dynamics and modelling of ocean waves. Cambridge University Press

Mentaschi L, Besioa G, Cassolab F, Mazzinoa A (2015) Performance evaluation of Wavewatch III in the Mediterranean Sea. J Ocean Model 90: 82-94. doi:10.1016/j.ocemod.2015.04.003

Tolman HL (1992) Effects of numerics on the physics in a thirdgeneration wind-wave model. J Phys Oceanogr 22:1095-1111. doi:10.1175/1520-0485(1992)022<1095:EONOTP $>2.0 . C O ; 2$

Tolman HL (2002) Validation of WAVEWATCH III version 1.15 for a global domain. Technical note 213, NCEP/NOAA/NWS, National Center for Environmental Prediction, Washington DC

Tolman HL(2014) User manual and system documentation of WAVEWATCH III version 4.18

van Lieshout PS, den Besten JH, Kaminski ML (2016) Validation of the Dang Van multiaxial fatigue criterion when applied to turret bearings of FPSO offloading buoys. J Ships Offshore Struct 1-9. doi: 10.1080/17445302.2016.1182461

Voorrips AC, Makin VK, Hasselmann S (1997) Assimilation of wave spectra from pitch-and-roll buoys in a North Sea wave model. J Geophys Res 102:5829-5849. doi:10.1029/96JC03242 